SISTEMA

\title{
Conflitos no licenciamento ambiental de PCHs: os casos de Dois Saltos e Água Limpa
}

\section{Conflicts in the Environmental License of SHPs: The Cases of Dois Saltos and Água Limpa}

\author{
Flávia de Faria GOMES ${ }^{1 *}$, Christian Luiz da SILVA ${ }^{1}$ \\ ${ }^{1}$ Universidade Tecnológica Federal do Paraná (UTFPR), Curitiba, PR, Brasil. \\ *E-mail de contato: fladfgomes@gmail.com
}

Artigo recebido em 10 de julho de 2017, versão final aceita em 14 de novembro de 2017.

RESUMO: A Política Nacional do Meio Ambiente (Lei 6.938/1981) foi um marco que incluiu o componente ambiental na gestão de políticas públicas, além de um avanço democrático na vida política. O seu principal instrumento, o licenciamento ambiental, é o responsável pelo estabelecimento de empreendimentos potencialmente impactantes, como as hidrelétricas, mas seu processo tem incitado o surgimento de inúmeros conflitos e embates sociais. Portanto, a pesquisa objetiva compreender a dinâmica da controvérsia em torno do licenciamento ambiental, especialmente das pequenas centrais hidroelétricas (PCHs) do Paraná. Caracteriza-se como qualitativa e explicativa; de delineamento metodológico bibliográfico; e aplicada, quanto à sua natureza e ao seu resultado. É baseada em livros, artigos científicos, estudos ambientais preliminares do Instituto Ambiental do Paraná, informações da Agência Nacional de Energia Elétrica e em reportagens de mídias locais. Parte de dois estudos de caso conflituosos. Os dados demonstram que o Paraná tem visado às $\mathrm{PCH}$ e que estas permeiam diferentes atores e embates. Verifica-se que o problema não está na capacidade do instrumento, mas na incapacidade de gestão deste, ou seja, dos seus gestores, que têm condicionado este cenário. E a identificação da questão institucional (arranjo, regras e atores - junto da percepção destes sobre o processo) é o que propicia um melhor entendimento deste cenário e das possibilidades de melhoria do instrumento.

Palavras-chave: licença ambiental; hidrelétrica; conflito.

ABSTRACT: The National Environment Policy (Law 6.938/1981) was a milestone that included the environmental component in the management of public policies, as well as a democratic progress in political life. Its instrument, the environmental licensing, is responsible for establishing potentially impactful projects, such as hydroelectric power, but its process has incited the emergence of numerous social conflicts and clashes. Therefore, the research aims to understand the dynamics of the controversy surrounding the environmental licensing, specifically in small hydropower plants (SHPs) of Paraná. It is characterized as qualitative and explanatory; bibliographic methodological design; and applied, about nature and result. It is based on books, scientific articles, and preliminary environmental studies of the Environmental Institute of Paraná, information from the National 
Electric Energy Agency and reports from local media. Based on two studies of conflicting cases. The data demonstrates that Paraná has aimed to SHP; that permeates different actors and conflicts. It appears that the problem is not about the capability of the instrument, but in the inability of his management, made by their managers, which has conditioned this scenario. The identification of the institutional issue (arrangement, rules and actors - with their perceptions about the process), is what provides a better understanding of this scenario and the opportunities for improving the instrument.

Keywords: environmental license; hydropower; conflict.

\section{Introdução}

As interpretações de mundo (e das políticas públicas e legislações), culturalmente originadas por transferências de conhecimentos, valores e normas, variam entre as diferentes sociedades e ambientes existentes (North, 1993) e, a partir disso, conjecturam-se em uma gama de possibilidades de desenvolvimento do país/estado/região. Ademais, o pensamento científico-tecnológico há muito limitou-se pela competitividade internacional (produtiva), que não considerava o social como núcleo de racionalidade política e fragmentava o desenvolvimento tecnológico (dos projetos técnicos que o integram) ao setor da economia (Vaccarez$\mathrm{za}, 2011)$. Sob esta perspectiva, considerando as múltiplas interpretações envolvidas, as políticas (por si só) e os projetos técnicos não são garantia de democracia efetiva.

Como consequência, acentuam-se cada vez mais o interesse e a atuação de diversos grupos sociais nacionais, que têm recebido apoio internacional (Little, 2003). No Brasil, houve uma mudança na gestão pública, uma redefinição de papéis baseada no aumento do número de atores sociais envolvidos na elaboração de políticas públicas e o rompimento com modelos não democráticos, implicando no surgimento de novos arranjos institucionais (Coletti, 2012). De maneira geral, essa movimentação - ambientalismo - tem ganhado força a partir de sanções, inclusive internacionais, que se disseminam no país.
O Brasil tornou-se uma importante referência para as discussões ambientais e temas correlatos e, por isso, a ação governamental na área foi ampliada, com a criação de vários programas e instituições. Essa consolidação institucional foi favorecida pela atualização e pela criação de legislações e normatizações, instrumentos políticos e instâncias públicas de participação, que fortaleceram e normatizaram as intenções e ações ambientais (Little, 2003).

Como exemplo, tem-se a Política Nacional do Meio Ambiente (PNMA), que surgiu com o intuito de contribuir com a implementação de grandes projetos técnicos, tirando o foco apenas de atividades poluidoras e concentrando as atenções nas que utilizam os recursos ambientais e que possuem potencial de degradar o ambiente. Por meio do licenciamento ambiental e da avaliação de impacto ambiental, esta política compatibiliza as diferentes variáveis de um projeto/atividade (Brasil, 1981).

O licenciamento ambiental é um processo administrativo que licencia a localização, a instalação, a ampliação e a operação de empreendimentos e atividades que poluam ou degradem potencialmente o meio ambiente. É um ato normativo cujos procedimentos são dependentes de normas gerais da União, que norteiam os órgãos ambientais federais, estaduais e municipais (Brasil, 1981). Em outras palavras, o licenciamento ambiental tem sido um dos principais instrumentos da Política Nacional do Meio Ambiente a propiciar o estabelecimento das intenções nacionais sobre o setor energético, 
uma vez que viabiliza a instalação e a operação de grandes empreendimentos e atividades no país. Contudo, o desenvolvimento desses projetos é a origem de grande parte dos conflitos ambientais observados no país (Zhouri, 2011).

Diante do exposto, objetiva-se explorar o universo da aplicação do licenciamento ambiental sobre empreendimentos hidrelétricos, compreender a dinâmica da controvérsia em torno do instrumento, com foco nas pequenas centrais hidrelétricas (PCHs), uma vez que estas têm sido alvo de um maior interesse em várias regiões do país, inclusive no Estado do Paraná, que será o recorte de estudo desta pesquisa.

\section{Conflito ambiental}

O conflito ambiental de países em desenvolvimento evidencia a distribuição e a apropriação dos recursos naturais e envolve diferentes culturas e comportamentos. Acselrad (2004) intitula esse tipo de conflito como sendo "ambiental"; Little (2003) utiliza o termo "socioambiental"; Guha \& Martinez-Alier (1997) falam de conflitos "ecológicos e distributivos"; Bullard (1993) aborda o "movimento de justiça ambiental", etc. Quando examinados estes e outros autores de referência, e os termos e conceitos utilizados por cada um, percebe-se que não há como distingui-los com precisão. Por serem tão similares, pode-se considerar que cada autor tem o seu modo de chamar o conflito que envolve o "meio ambiente", e talvez não existam diferentes tipos de conflito "ambiental", mas diferentes formas conceber aquele que envolve o território, seus recursos e as diferentes concepções dos atores envolvidos.

Contudo, levando em conta a crescente complexidade desse campo, atualmente é considerado como híbrido, por estar inserido em diversas áreas e linhas de estudo. Existem duas grandes perspec- tivas: uma está relacionada à política, à crítica ao modelo de desenvolvimento e ao estilo de vida que promove; e a outra relaciona-se às ciências sociais. A primeira aborda o paradigma do desenvolvimento sustentável, a gestão ambiental e as políticas públicas; a segunda explica o surgimento do movimento ambientalista, das diferentes percepções do meio ambiente, dos conflitos gerados e analisa as estratégias utilizadas (Alonso \& Costa, 2002).

O conflito ambiental envolve grupos sociais que se apropriam diferenciadamente do território (uso e significação) e origina-se "quando pelo menos um dos grupos tem a continuidade das formas sociais de apropriação do meio que desenvolvem, ameaçada por impactos indesejáveis", disseminados pelos recursos naturais, mas provocados pelas práticas de outros grupos. Ocorrem pela apropriação de uma mesma base de recursos, ou de bases distintas, mas com ecossistemas interconectados. Acontecem em "unidades territoriais compartilhadas por um conjunto de atividades" com um "acordo simbiótico", rompido em função dos impactos indesejáveis citados (Acselrad, 2004, p. 25).

Há os conflitos ambientais tecidos por um comportamento autoritário e, nas últimas décadas, emergem os provocados pela desregulamentação das normas e agências públicas ambientais. A partir disso, são empregadas na agenda pública as tecnologias ditas "do consenso", que encobrem lacunas sociais, pendências judiciais, etc., e são caracterizadas justamente pela despolitização. Os confrontos remanescentes são encarados como uma falha no processo do consenso e não como uma diferença real existente entre os atores sociais e os projetos ou atividades propostas - promove-se uma “indiferenciação social” (Acselrad, 2004).

É importante considerar que existem três tipos de conflitos ambientais: a) os conflitos ambientais distributivos indicam desigualdades sociais no 
acesso e na utilização dos recursos naturais e tratam basicamente de recriminar a elite que vive em função do meio ambiente de localidades mais pobres; b) os conflitos ambientais espaciais são provocados por impactos ambientais que vão além de limites estabelecidos entre os territórios de diferentes atores sociais; c) os conflitos ambientais territoriais partem da sobreposição de reivindicações, provenientes de distintos segmentos sociais, quanto às suas identidades e lógicas sociais, sobre um mesmo recorte espacial. Os envolvidos apresentam distintos modos de apropriação do meio ambiente (Zhouri \& Laschefski, 2010, p. 18-23).

Neste último tipo de conflito, o planejamento territorial é transferido às instâncias públicas que, em uma relação dialética, tentam influenciar o setor empresarial. Mas, as empresas têm se tornado agentes independentes, ao criarem suas próprias espacialidades e territorialidades, na busca de novas localizações e/ou mercados. "A territorialidade empresarial está cada vez mais caracterizada por temporalidades, ou seja, por desterritorializações e reterritorializações". Muitas vezes o Estado se alia a segmentos do capital, e se opõe às outras territorialidades (Zhouri \& Laschefski, 2010, p. 24).

Tendo sido postos os tipos de conflitos, pode-se compreender que as sociedades têm sua existência produzida basicamente pelos modos de apropriação do mundo material, dentre as quais distinguem-se três tipos de práticas (Acselrad, 2004):

a) As formas técnicas de apropriação evidenciam os modos de "uso, transformação biofísica, extração, inserção e deslocamento de materiais", os quais são resultantes de diversos saberes, enquanto servem de base para o surgimento de novos conhecimentos - visam a um fim exclusivamente material;

b) As formas sociais de apropriação destacam os processos de diferenciação social, considerando as "estruturas desiguais de distribuição, acesso, posse e controle de territórios ou de fontes, fluxos ou estoques de recursos materiais". Abordam as dinâmicas de reprodução e os padrões de desigualdade das sociedades;

c) As formas culturais de apropriação referem-se às diferentes atribuições de significado (fatos culturais) sobre o mundo material, dando a este novos sentidos e ordenamentos. "Significação do espaço biofísico".

Quer dizer, os atores transformam o meio biofísico de maneira mais direta a partir das formas técnicas, mas estas também são condicionadas pelas formas sociais e culturais - tipos de sociedade e os modelos culturais. As formas técnicas são, então, baseadas em contextos históricos, que condicionam os padrões de ação e, especialmente, as percepções e orientações que legitimam tais práticas. Os modos sociais articulam as formas técnicas ("definidas por sua espacialidade e temporalidade"), as formas sociais (padrões de desigualdade sobre a apropriação dos recursos) e as formas culturais ("valores e racionalidades que orientam as práticas sociotécnicas"). Todas relacionam-se por meio dos "acordos simbióticos", necessários entre as práticas sociais (Acselrad, 2004, p. 16).

Por fim, o quadro conflitivo possui duas categorias de anunciação: a) a durabilidade trata da continuidade da base material, que sustenta diversas formas sociais, e é considerada como um critério que legitima ou deslegitima as práticas de apropriação; b) a interatividade opõe os atores sociais, por considerar as distintas formas de apropriação dos elementos de um território, ou de territórios conexos, e é entendida como uma externalidade (financeira) de uma prática sobre outra (Acselrad, 2004). 


\section{A trajetória do conflito no setor energético}

Desde o final do século XIX, a hidroeletricidade se destaca no Brasil quando o assunto é geração de energia elétrica, principalmente após o discurso de que utilizam-se de fontes limpas de energia. No que diz respeito aos discursos, a propósito, os defensores da instalação de usinas abordam a autoridade científica, a dessubjetivação dos grupos diretamente afetados e a promoção do desenvolvimento (empregos e serviços públicos). Por outro lado, os que se opõem às usinas manifestam os impactos ambientais produzidos por esse tipo de empreendimento (apesar de utilizar fonte limpa) e o impacto negativo que promovem sobre as populações ribeirinhas - como o deslocamento, o desinteresse quanto aos seus meios de subsistência, etc. (Rampazo \& Ichikawa, 2013).

Como consequência, na segunda metade da década de 1970, ações de resistência começaram a se estruturar (movimentos sociais de abrangência regional ou isolados) e a questionar esse tipo de empreendimento, bem como a política energética nacional, principalmente quando era previsto mais de um sobre uma mesma bacia hidrográfica. Surgiu o Movimento dos Atingidos por Barragens no Brasil, que reivindicava a garantia de indenização justa, a inclusão de famílias sem documentos de posse nessa garantia, a oposição à construção de barragens ou, pelo menos, a alteração de seus projetos, bem como pediam por uma maior democratização no país (Foschiera, 2009).

Neste momento, o Estado não intervinha diretamente na economia, mas sobre a garantia de expansão do capital, promovendo a necessidade do controle sobre a natureza. Consequentemente, o setor elétrico se reestruturou (Foschiera, 2009), visando à privatização do setor, deixando ao Estado as ações indicativas e o papel de fiscalizador. Mas, posteriormente, as privatizações foram paralisadas e o Estado se reinseriu no processo, participando de consórcios de geração de energia, mas mantendo as políticas neoliberais (Foschiera, 2009).

Com isso, os movimentos que se opunham às barragens notaram que a ideia de participação por meio da tomada de poder do Estado não seria viável, pois este acelerava a construção de grandes barragens por meio de incentivos financeiros. Um número pequeno de empresas passou a controlar o setor elétrico, impactando comunidades locais e o meio ambiente. Enquanto isso, avançava o ativismo de diferentes grupos de oposição, visando a ações conjuntas e mais articuladas (Foschiera, 2009).

\subsection{Conflitos em licenciamentos ambientais do setor}

A política energética é estratégica para o processo de desenvolvimento do país, já que a energia é a base de políticas industriais e de desenvolvimento tecnológico; paralelamente, salienta o embate entre as políticas de infraestrutura e ambiental. Esse embate se estruturou principalmente após a inserção do licenciamento ambiental sobre a análise de viabilidade dos empreendimentos (Fonseca, 2013).

Por isso, o licenciamento é um processo considerado referência na promoção de conflitos. $\mathrm{Na}$ cadeia produtiva de $\mathrm{PCHs}$, por exemplo, no que diz respeito aos recursos naturais, o licenciamento ambiental é tido como o maior limitante observado, por isso, é considerado um dos fatores que devem ser priorizados na tomada de ações, para orientar a formalização de políticas (Silva et al., 2016). Cada licença emitida é proveniente de um processo de negociações técnicas e políticas e repercute as intenções dos diferentes atores envolvidos, promovendo inúmeros efeitos sobre a sociedade. Neste cenário, as controvérsias resultantes de diversos projetos 
ganham importância ao representar uma articulação entre o saber técnico e a dinâmica política (Fleury \& Almeida, 2013).

Essa articulação denota um avanço institucional, contudo, o licenciamento ambiental sofre críticas, por atuar em meio a conflitos sobre a apropriação social da natureza que dizem respeito a diferentes modos de conceber o território e seus usos (Zhouri, 2011). Isto acontece, principalmente, devido às estratégias que flexibilizam a política ambiental, utilizadas pelos licenciadores, que fazem com que o instrumento impulsione uma série de injustiças, comprometendo as comunidades atingidas, em diferentes aspectos, pois ameaça direitos garantidos e atenua a aplicação de normas ambientais. Essa assimetria de poder provocada revela a fraqueza do sistema político e da legislação ambiental (Zucarelli, 2011).

As flexibilizações acabam por transferir determinada etapa do licenciamento para outras esferas, como o judiciário, evidenciando a debilidade do instrumento como instância de participação e regulação, principalmente quanto à viabilidade socioambiental de empreendimentos (Zhouri \& Gomes, 2011). Essa debilidade promove a longevidade do conflito e expressa uma contradição, onde a proposta de desenvolvimento é incompatível com a concepção socioambiental e com os saberes, práticas e intenções da comunidade local, os quais visam à qualidade de vida e são, portanto, considerados prioritários (Fleury \& Almeida, 2013).

Por outro lado, muitos empreendedores escondem ou minimizam os conflitos, enquanto a comunidade afetada e os ambientalistas os evidenciam. Mas, aqueles partem de uma avaliação econômica e estes, de uma social. Isso ocorre, principalmente, em regiões que ainda não estabeleceram sua economia de mercado de maneira plena e que, por isso, necessitam de incentivos. A partir disso, programas regionais de desenvolvimento presumem que a região possui determinada aptidão, sem considerar outras dimensões que não a econômica (Bermann, 2007).

O estudo de impacto ambiental tem sido considerado superficial, por desconhecer que o impacto ambiental envolve também essas outras dimensões, para favorecer o empreendimento. Ademais, a sua apresentação é feita pelo empreendedor, que valoriza medidas que favorecem o empreendimento, e não os seus possíveis efeitos (Piagentini \& Favareto, 2014). Enquanto isso, os interessados em contribuir com a tomada de decisão encontram dificuldades na participação, pois não há consenso e nem negociação, apenas o estabelecido por grupos mais fortes politicamente. O envolvimento social é limitado e, por vezes, inexistente (Bermann, 2007).

Além disso, os recursos hídricos potenciais são desprezados pelas políticas regionais, que também não têm objetivado proporcionar retornos socioeconômicos e ambientais para os locais e comunidades impactadas, principalmente quando se trata da construção de hidrelétricas. O estudo de impacto não possui medidas de salvaguarda social e dificilmente cria possibilidades de sustento ou promove o desenvolvimento local (Siciliano et al., 2015; Oliveira et al., 2016).

No Brasil, é responsabilidade da esfera governamental decidir se um empreendimento é viável, enquanto o seu papel de mediador nas discussões sobre a instalação de empreendimentos fica obscurecido (Andrade \& Dos Santos, 2015). Somados às lacunas e limitações observadas, o crescimento da demanda energética, a democracia incipiente, as privatizações e os movimentos sociais permitem o entendimento da relação das controvérsias do setor energético com a política e o planejamento nacional (e/ou regional) (Schaeffer \& Smits, 2015). 


\section{Procedimentos metodológicos}

Para a escolha dos estudos de caso que subsidiam esta pesquisa, foi utilizado o site do Instituto Ambiental do Paraná, que disponibiliza os estudos preliminares de 181 empreendimentos que pretendem se estabelecer no Estado, considerando um recorte de tempo que vai de 2010 a 2016. Destes, 83 correspondem ao licenciamento de $\mathrm{PCHs}$ - as quais têm sido a preferência do estado. As PCHs são muito visadas, dentre outras coisas, por se adaptarem facilmente a diferentes condições de queda, de acordo com as especificidades (tipos topográficos e cartográficos) das diversas localidades escolhidas para implementá-las (Ortiz Flórez, 2014). Além disso, o Plano Nacional de Expansão de Energia 2023 promete priorizar o grande potencial energético para fontes renováveis de energia, a fim de atender o futuro aumento do consumo no país, e a previsão de maior investimento está posta sobre a energia hidráulica.

Em relação aos empreendimentos hidrelétricos, a Resolução Conjunta SEMA/IAP n ${ }^{\circ}$ 09/2010, que dá nova redação à de $n^{\circ} 05 / 2010$, estabelece que PCHs (até então baseadas apenas no Relatório Ambiental Simplificado - RAS) acima de $10 \mathrm{MW}$ (até $30 \mathrm{MW}$ ) serão enquadradas na Resolução Conama $n^{\circ}$ 01/1986, passíveis de apresentação do estudo de impacto ambiental e seu respectivo relatório (EIA/RIMA) e da realização de audiências públicas, conforme Resolução Conama nº 09/1987. Enquanto isso, as PCHs de potência menor do que 10MW continuam sendo submetidas ao RAS. A partir disso, e objetivando tratar de estudos mais complexos, foi considerado pertinente dar atenção apenas aos estudos baseados no EIA/RIMA, que somam 40.

A segunda etapa de definição dos casos envolveu o site da Agência Nacional de Energia Elétrica (ANEEL) que, com o Banco de Informações de
Geração, oferece informações sobre diversos empreendimentos geradores de energia, em diferentes estágios e regiões do país. No que diz respeito às PCHs no Estado do Paraná, foram encontradas 30 em estágio de operação, duas em construção e 16 com construção não iniciada, somando 48 empreendimentos. A terceira etapa ocorreu com o intuito de cruzar as informações encontradas no IAP e na ANEEL. Como resultado, dos 40 estudos de PCHs baseados em EIA/RIMA no IAP, apenas 10 relacionavam-se com as informações da ANEEL. Ou seja, os outros 30 permanecem em estágio de estudos no IAP. Dos 10 que avançaram, sete estão em construção não iniciada (na fase de licença prévia) e três em operação (licença de operação).

Deste modo, a quarta etapa objetivou selecionar os estudos/empreendimentos, de acordo com a quantidade de situações conflituosas. Dos 10, apenas quatro apresentaram situações significativas, observadas em diferentes canais de informação. Mas, a PCH Dois Saltos e a PCH Água Limpa foram escolhidas para subsidiar o estudo, pela quantidade e pela complexidade das manifestações. A primeira foi submetida ao IAP em 2011 e a segunda em 2012, mesmo assim, as duas possuem apenas a licença prévia, ou seja, configuram-se ainda como estudo.

A análise de conteúdo contou com três fases, de acordo com Bardin (2011): descrição, inferência e interpretação. Seguindo a linha da autora, os dados brutos foram organizados e agregados em unidades, as quais permitem a descrição das características pertinentes ao conteúdo. Para este fim, foi utilizado o software ATLAS.ti, que auxilia na análise qualitativa de grandes corpos de texto (dentre outros formatos), apoiando o pesquisador na organização, na reconfiguração e na gestão do material, de forma sistemática. Em especial, este software foi escolhido por permitir trabalhar simultaneamente com vários documentos e por codificá-los e classificá-los ao 
mesmo tempo - uma vez que este estudo abordou dois casos, mas também os analisou conjuntamente.

Na codificação, frases ou parágrafos (unidades de contexto) foram vinculados à um segmento de conteúdo (unidade de registro). Foram então formadas seis unidades de registro: arbitrariedades, envolvimento do MP-PR, envolvimento político, envolvimento do setor privado, resistências sociais e desdobramentos. Estas foram categorizadas (ou separadas em famílias), diferenciadas e, em seguida, reagrupadas (por analogia). Isto é, foram reunidos grupos de elementos sob determinado título, formando três categorizações: arbitrariedades, enfrentamentos e desdobramentos. A codificação e a categorização serviram para racionalizar os dados e auxiliar no processo de análise qualitativa, uma vez que o software organiza, registra e possibilita o acompanhamento dos registros efetuados, contribuindo com a integração das informações.

\section{Diagnóstico dos casos}

\subsection{PCH Dois Saltos}

A empresa responsável pelo projeto intitula-se Dois Saltos Empreendimentos de Geração de Ener- gia Elétrica Ltda., parceria entre a Companhia Paranaense de Energia (Copel) e a Santa Clara Indústria de Pasta e Papel Ltda. Está prevista para o município de Prudentópolis, no Estado do Paraná, mais especificamente no Rio dos Patos, na bacia do rio Ivaí. As duas empresas gestoras já são responsáveis por outras centrais de geração e no trecho médio inferior do Rio dos Patos já existem outras instaladas. Mas, este rio é utilizado principalmente para a geração de energia e para o lazer e turismo. Devido à presença de diversos rios, existem inúmeras quedas d'água na região e algumas são consideradas as mais altas do Brasil. Com isso, Prudentópolis é conhecida, e se autodenomina, como a "Terra das Cachoeiras Gigantes" (LACTEC, 2011).

$\mathrm{O}$ município possui sua economia voltada à agricultura e à pecuária, mas concebe as atividades ligadas ao ecoturismo como um grande potencial a ser explorado - pois já atua com o segmento de turismo de eventos, pautado na realização de festas folclóricas e tradicionais da cultura ucraniana e da festa nacional do feijão preto - já que é a maior produtora deste grão no Estado do Paraná. O EIA/ RIMA da PCH Dois Saltos foi apresentado ao IAP no ano de 2011. Nele, a Área de Influência Direta (AID) do empreendimento prevê abranger duas cachoeiras, por isso, a quantidade de água a ser

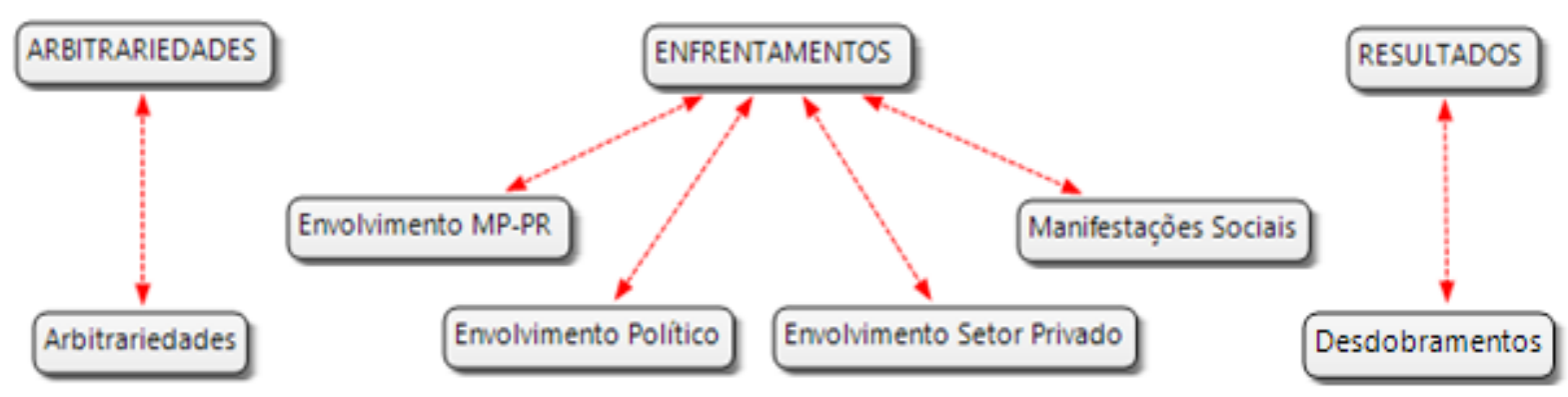

FIGURA 1 - Resultados das codificações e categorizações feitas no ATLAS.ti.

FONTE: Gomes (2017). 
mantida nestes locais necessitaria de cuidados especiais. Foram elaborados medidas e programas para compensar e minimizar os impactos relacionados à alteração do cenário paisagístico nestes locais (LACTEC, 2011).

A ANEEL concedeu a outorga para operar no Rio dos Patos, mas o empreendimento permanece na fase de licença prévia. Os principais impactos previstos para a implementação deste empreendimento, dispostos em seu estudo de impacto, estão associados à qualidade da água, ao lazer e ao turismo. Três impactos foram considerados, nesta pesquisa, como sendo de maior potencial de embate social: a) alteração do cenário paisagístico em alguns períodos no trecho de vazão reduzida, ou seja, a quantidade de água que passa sobre os saltos (Manduri e Barão do Rio Branco); b) alteração na qualidade das águas durante a operação do empreendimento, devido ao trecho de vazão reduzida, já que a inserção de atividades humanas ou o lançamento de efluentes poderá aumentar esse impacto e existe a possibilidade de contaminação por óleos e graxas das máquinas da casa de força; c) alteração de elementos da composição paisagística, devido à implantação de estruturas necessárias ao empreendimento (LACTEC, 2011).

Existe um conjunto de programas e medidas previstos para atuar sobre estes possíveis impactos, entretanto, estas promessas não têm sido suficientes para tranquilizar a comunidade de Prudentópolis e arredores. Por isso, estes possíveis impactos promoveram inúmeras manifestações, configurando um conflito ambiental que se apresenta antes mesmo da implantação do empreendimento (LACTEC, 2011).

\subsubsection{Manifestações envolvendo a PCH Dois Saltos}

Estão dispostos na Tabela 1, em forma de linha do tempo, as principais manifestações relacionadas à implementação da $\mathrm{PCH}$ Dois Saltos - provenientes de uma pesquisa realizada em sites de jornais, blogs, páginas de movimentos sociais, no Ministério Público do Paraná, em dissertação, monografia, artigos científicos e processos judiciais específicos.

TABELA 1 - Resumo das manifestações relacionadas à PCH Dois Saltos

\begin{tabular}{cl}
\hline Data & \multicolumn{1}{c}{ Situações } \\
\hline $01 / 12$ & $\begin{array}{l}\text { Ação popular contra o IAP e a Dois Saltos Empreendimentos. Alega irregularidades no processo de licenciamento } \\
\text { (Estado do Paraná, 2012) }\end{array}$ \\
\hline $01 / 12$ & $\begin{array}{l}\text { Membro do MP-PR solicitou complementações do EIA/RIMA e uma nova audiência pública para expor estas } \\
\text { questões (Intervalo da Notícia, 2012a). }\end{array}$ \\
\hline $01 / 12$ & $\begin{array}{l}\text { Em audiência pública, questionou-se o modo como foi feita a pesquisa com a população. O aceite não confere com } \\
\text { a realidade (Intervalo da Notícia, 2012a). }\end{array}$ \\
\hline $05 / 12$ & $\begin{array}{l}\text { Movimento solicitou colaboração técnica na elaboração de uma pauta para reunião junto ao IAP (Movimento } \\
\text { Gigantes, 2012). }\end{array}$ \\
\hline $06 / 12$ & $\begin{array}{l}\text { Movimento fez a reportagem “População de Prudentópolis realiza manifestação contra construção de usina”, para } \\
\text { ser disseminada na mídia (Movimento Gigantes, 2012). }\end{array}$ \\
\hline $\begin{array}{l}\text { A reportagem foi divulgada pela imprensa, com diferentes títulos: "População de Prudentópolis realiza } \\
\text { manifestação contra construção de usina”; "Moradores de Prudentópolis saem às ruas protestar contra construção } \\
\text { de usinas"; "Prudentopolitanos se manifestam contra construção de usina hidrelétrica” (Rede Sul de Notícias, } \\
\text { 2012; Irati Notícias, 2012; Lobo Notícias, 2012). }\end{array}$ \\
\hline
\end{tabular}


TABELA 1 - Conclusão

Manifestante contrário à PCH relatou que os representantes políticos estufam o peito para falar da Terra das

06/12 Cachoeiras Gigantes e do forte desejo de ver a região se tornar um polo turístico, mas, agora que tudo isso pode ser comprometido, eles silenciam (Rede Sul de Notícias 2012; Irati Notícias, 2012; Lobo Notícias, 2012).

Comparecimento no I Fórum do Desenvolvimento do Turismo em Prudentópolis, com a intenção de manifestar

06/12 a indignação em relação à PCH. Conseguiram agendar reunião com alguns representantes para discutir o assunto (Movimento Gigantes, 2012).

06/12 Secretário do Meio Ambiente conversou com a comissão contrária à PCH, que se manifestou no evento anterior (Intervalo da Notícia, 2012b).

06/12 Reportagem "Projeto de hidrelétrica revolta Prudentópolis". Representante do Movimento Gigantes e a assessoria de imprensa da Copel foram entrevistados (Diário dos Campos, 2012).

06/12 Reportagem "Prudentopolitanos se manifestam contra a construção de usina hidrelétrica". Evidencia os pontos negativos da instalação do empreendimento (Lobo Notícias, 2012).

Reportagem "Construção de usina ainda não tem data para começar". Trata de crise do IAP, devido a um suposto

10/12 conflito de interesses sobre as LPs concedidas no estado, envolvendo empreendimentos ligados a familiares do Secretário do Meio Ambiente (Folha Centro Sul, 2012).

Reportagem "Prudentópolis não quer PCH”. Presidente de partido local diz que não foram consideradas as manifestações nas audiências públicas e que há falhas no EIA. Os protestos chegaram à Comissão do Meio Ambiente da Assembleia Legislativa e ao MP-PR, que investiga o conflito de interesses na liberação de LP's (Folha Centro Sul, 2012). Processo judicial da empresa Archgeo sobre a Dois Saltos Empreendimentos. Alega quebra de contrato. Expõe

01/13 que houve apenas uma única reunião técnica com toda a equipe (meios biótico, físico e socioeconômico), para apresentação e análise do diagnóstico, impactos e propostas de mitigação (Estado do Paraná, 2013a).

02/13 Processo judicial da Santa Clara Indústria de Pasta e Papel Ltda., sobre a Copel. Ambas são sócias na Dois Saltos

02/13 Empreendimentos (Estado do Paraná, 2013b).

04/13 Dissertação "Matriz e índice de avaliação de impactos ambientais para a implantação de PCHs". Usa a PCH Dois Saltos, e seus conflitos, como estudo de caso (Bastos, 2013).

Reportagem “Usina hidrelétrica será construída em Prudentópolis”. Liderança política diz que o presidente do IAP

05/13 se comprometeu a ouvir a versão dos "contrários" antes de emitir licença, mas não o fez. A população preocupa-se com o turismo, pois, com a falta de informações, não se sabe como será executado, quem estará envolvido, quem será favorecido (Folha Centro Sul, 2013).

08/14 Reportagem "População quer impedir obra de PCH". Entrevista o Movimento Gigantes e o IAP (Gazeta do Povo, 2014).

09/14 Artigo "O estado do Paraná no alvo das eletroestratégias". Cita o caso da PCH Dois Saltos. Foi apresentado em evento da Unicentro (Albuquerque \& Andrade, 2014).

14 Monografia "Conflitos socioambientais ocasionados por pequenas centrais hidrelétricas no município de

_- 14 Prudentópolis-PR; o caso da PCH Dois Saltos”, da Universidade Federal do Paraná (Andrade, 2014).

05/15 Dissemina reportagem "PCH Dois Saltos de 25 MW recebe outorga da ANEEL para operar no Rio dos Patos, no Paraná” (Portal PCH; Rádio Najuá, 2015).

01/16 Audiência pública em Prudentópolis - ausência de autoridades locais, presença de líderes políticos e grande representação da população (Intervalo da Notícia, 2012a).

Foram entregues documentos ao promotor de justiça responsável pela proteção do meio ambiente de

02/16 Prudentópolis. Falam de algumas leis de uso e ocupação do solo e as PCHs com anuência do município (Movimento Gigantes, 2016).

FONTE: Adaptado de Gomes (2017). 
O foco deste diagnóstico foi perceber a quantidade e a constância das manifestações na primeira fase do licenciamento ambiental e verificar quais são os principais atores envolvidos no conflito ambiental estabelecido.

\subsection{PCH Água Limpa}

Este projeto possui a empresa Multifase - Centrais de Energia do Brasil Ltda. como sua responsável e pretende se estabelecer na região Noroeste do Estado do Paraná, mais especificamente entre os municípios de Mariluz, Alto Piquiri e Perobal, no rio Goioerê, na bacia do rio Piquiri. Perto da área prevista para o barramento existe uma cachoeira chamada Salto Paiquerê, sobre a qual se espera, durante o período de seca, a liberação de vazão para manutenção dos atributos naturais. A atividade agropecuária é predominante na área de influência do empreendimento. A cidade de Perobal ainda conta com muitos de moradores nas áreas rurais, mas as áreas urbanas de Mariluz e Alto Piquiri concentram a maior parte da população (Cia. Ambiental, 2012).

O EIA/RIMA deste empreendimento foi apresentado ao IAP no ano de 2012 e assegura que haverá o alagamento de terras e a necessidade de restaurar áreas de preservação permanente (APP) no entorno do reservatório - podem comprometer o desenvolvimento de determinadas atividades produtivas. As APPs atingirão edificações e infraestruturas, por essa razão, em algumas partes é considerada a transferência dessas estruturas, além da redução de porção da APP próxima a essas regiões, a fim de prevenir impactos sociais. Ademais, também existe a possibilidade de acidentes envolvendo combustíveis e outros produtos perigosos, podendo levar a alterações nos diversos meios (físico, biótico e socioeconômico) (Cia. Ambiental, 2012).
Foram registradas duas Unidades de Conservação (UCs) na área de influência indireta (bacia do Goioerê) - a Reserva Biológica das Perobas e a RPPN Fazenda Palmar - e a existência de uma Área Prioritária para Conservação do Bioma Mata Atlântica (APC Rio Goioerê) na área do rio prevista para implantação do reservatório, além de ter sido evidenciada a existência de sítios arqueológicos no vale do rio. O projeto do empreendimento abrange uma área de 1.300 ha, incluindo a extensão do reservatório, as áreas construídas, a área de preservação permanente e a calha do rio. Esta extensão interferirá em 26 propriedades de um assentamento regularizado pelo INCRA (Nossa Senhora Aparecida). O estudo de impacto conta com a proposição de diversos planos e programas de controle e monitoramento ambiental, que também não foram suficientes para conter a população que poderá ser afetada pelos impactos da implementação do empreendimento (Cia. Ambiental, 2012).

Esta proposta abrange o Salto Paiquerê, ligado a um processo de tombamento (iniciado devido à $\mathrm{PCH}$ ) que tramita no Conselho de Patrimônio Histórico e Artístico do Paraná, a partir de recomendação do MP-PR e de protocolo enviado pela Fundação de Apoio ao Desenvolvimento Científico e Tecnológico do Vale do Piquiri (FADCT). Em 2013, o salto recebeu o tombamento provisório - incidem sobre o bem os efeitos de um bem tombado, mesmo antes do trâmite final do processo. Em 2014 o processo já havia evoluído, mas não tinha sido votado. Antes disso, a Secretaria de Estado da Cultura expediu uma ordem para que os empreendedores explicassem a construção sobre o Patrimônio Histórico e o processo permaneceu em fase de instrução, ficando suspensa qualquer obra na região do salto. A empresa alegou que a PCH não afetará o salto (Gazeta do Povo, 2014). Enquanto isso, alguns atores se opõem à instalação do empreendimento. 


\subsubsection{Manifestações envolvendo a PCH Água Limpa}

Na Tabela 2 estão, em forma de linha do tempo, as principais manifestações relacionadas à implementação da PCH Água Limpa - provenientes de pesquisa realizada em sites de jornais, rádios, blogs, portais, páginas de movimentos sociais, do Ministério Público do Estado, em periódicos, relatórios. Busca-se perceber a quantidade e a constância das manifestações na primeira fase do licenciamento ambiental e verificar quais são os principais atores envolvidos no conflito ambiental estabelecido.

TABELA 2 - Resumo das manifestações relacionadas à PCH Água Limpa

\begin{tabular}{|c|c|}
\hline Data & Situações \\
\hline $07 / 12$ & $\begin{array}{l}\text { MP-PR produziu documento informativo sobre irregularidades na publicidade de audiência pública e do EIA do } \\
\text { empreendimento (CAOPMA, 2012a). }\end{array}$ \\
\hline $08 / 12$ & $\begin{array}{l}\text { MP-PR Relata o encontro do Movimento Pró Ivaí-Piquiri com a comunidade do Assentamento Nossa Senhora } \\
\text { Aparecida, que será impactado pela PCH. Estratégias de atuação foram discutidas, visando ao tombamento do Salto } \\
\text { Paiquerê pela Secretaria de Estado da Cultura e IPHAN (CAOPMA, 2012b). }\end{array}$ \\
\hline 09/12 & $\begin{array}{l}\text { Em determinado capítulo trata do conflito da PCH Água Limpa, ao explicar o funcionamento e as características de } \\
\text { uma PCH - Revista FAEP (Santos, 2012). }\end{array}$ \\
\hline $10 / 12$ & $\begin{array}{l}\text { Audiência pública em Alto Piquiri. Foi feita referência à publicação, naquele mesmo dia, de lei municipal do } \\
\text { município de Mariluz, declarando o trecho do Rio Goioerê no município como de interesse cultural, natural, } \\
\text { turístico, paisagístico, incluindo o Salto Paiquerê, o que inviabiliza, por si só, o licenciamento do empreendimento. } \\
\text { Foi requerida complementação dos estudos e uma nova audiência pública (Pró Ivaí-Piquiri, 2012). }\end{array}$ \\
\hline $10 / 12$ & pública em Perobal. Houve poucos presentes, devido à pouca divulgação sobre o ato (Pró Ivaí-Piquiri, \\
\hline $10 / 12$ & $\begin{array}{l}\text { Audiência pública em Mariluz, onde cerca de } 200 \text { pessoas compareceram. Representantes do empreendimento } \\
\text { aceitaram apresentar projetos energéticos alternativos, levando em consideração o veemente repúdio da sociedade } \\
\text { local à PCH (Pró Ivaí-Piquiri, 2012). }\end{array}$ \\
\hline $11 / 12$ & $\begin{array}{l}\text { Recomendação do Ministério Público ao presidente do IAP. Suspensão de licenciamento ambiental de empreendi- } \\
\text { mentos hidrelétricos em todo o estado (Pró Ivaí-Piquiri, 2012). }\end{array}$ \\
\hline $11 / 12$ & $\begin{array}{l}\text { Reportagem "Alto Piquiri - MP-PR recomenda o tombamento de trecho do Rio Goioerê". Ministério Público do } \\
\text { Paraná recomendou que o município de Alto Piquiri remetesse à Câmara Municipal o Projeto de Lei decretando o } \\
\text { tombamento do trecho do Rio Goioerê (abrangendo, também, o Salto Paiquerê), ou medida equivalente (MP-PR, } \\
\text { 2012). }\end{array}$ \\
\hline $11 / 12$ & $\begin{array}{l}\text { Reportagem "Tombamento de trecho de rio". Sobre recomendação do MP-PR para que o município de Alto Piquiri } \\
\text { remeta à Câmara Projeto de Lei decretando o tombamento do trecho do Rio Goioerê (Blog do Praxedes, 2012). }\end{array}$ \\
\hline $03 / 13$ & $\begin{array}{l}\text { MP-PR relatou sobre a audiência pública de complementação, que ocorreu em Mariluz. Foi lido o ofício da Secre- } \\
\text { taria de Estado da Cultura, tornando público o tombamento provisório do Salto Paiquerê. O documento foi entregue } \\
\text { ao IAP (CAOPMA, 2013). }\end{array}$ \\
\hline $04 / 13$ & $\begin{array}{l}\text { Reportagem "Abaixo assinado busca pelo tombamento do Salto Paiquerê". O propósito é entregá-lo à Secretaria de } \\
\text { Estado da Cultura (Portal da Cidade, 2013). }\end{array}$ \\
\hline $04 / 13$ & $\begin{array}{l}\text { Reportagem "Ambientalistas pedem tombamento do Salto Paiquerê". Sobre entidades de preservação do meio am- } \\
\text { biente que organizaram o abaixo-assinado (Goionews, 2013). }\end{array}$ \\
\hline $11 / 13$ & $\begin{array}{l}1^{a} \text { Trilha dos Rios, promovida pela Secretaria de Cultura de Alto Piquiri. Um de seus objetivos era debater a neces- } \\
\text { sidade de atividades de proteção dos locais visitados (Pró Ivaí-Piquiri, 2013) }\end{array}$ \\
\hline
\end{tabular}


TABELA 2 - Conclusão

03/14 Reportagem “Mobilização vai impedir construção de hidrelétricas no Apertado e Salto Paiquerê". Campus da UEM em Goioerê debateu sobre o assunto (Goionews, 2014).

04/14 FADCT encaminhou ofício ao Secretário da Cultura solicitando o tombamento do Salto Paiquerê e Recanto Apertado, junto de lista de assinaturas da comunidade (FADCT, 2014a).

04/14 Visita de especialistas na região das corredeiras, para a produção de estudos para o aproveitamento turístico das atrações (Pró Ivaí-Piquiri, 2014).

Reportagem "Fundação universitária pede oficialmente o tombamento do Salto Paiquerê e do Recanto do Aper-

05/14 tado". Tratou de solicitação de tombamento do Salto Paiquerê e do Recanto Apertado; reunião com membros do Conselho Estadual do Patrimônio Histórico e Artístico do Estado do Paraná; visita do CAOPMA/MP-PR (FADCT, 2014b).

08/14 Reportagem "Fundação quer impedir obra de PCH". Tratou da relação do pedido de tombamento do salto e da construção da PCH (Gazeta do Povo, 2014).

09/14 Artigo “O estado do Paraná no alvo das eletroestratégias". Cita o caso da PCH Água Limpa, em evento da Unicentro, em Guarapuava (Albuquerque \& Andrade, 2014).

11/14 Reportagem "Muitos debates na audiência pública sobre a Hidrelétrica de Apertados". Neste evento também foi discutido o processo de tombamento de Paiquerê e Apertado (Assis Online, 2014).

Reportagem "FADCT e comunidade do Vale do Piquiri se organizam para apreciar e defender seus recursos pai-

11/14 sagísticos". Trata da II Trilha dos Rios, onde um dos objetivos era sensibilizar os gestores sobre a região (FADCT, 2014c).

03/15 Reportagem "FADCT organiza evento em prol do Dia Internacional de Luta contra as Barragens". O objetivo era mostrar alternativas sustentáveis e os prejuízos sobre Apertados e Salto Paiquerê (FADCT, 2015).

Reportagem "População luta contra ameaças das hidrelétricas no Paiquerê e Apertado". Sobre protesto, no Dia

03/15 Mundial da Água, sobre destruição das belezas naturais dos Rios Goioerê e Piquiri; e o Dia Internacional de Lutas Contra as Barragens, pelos Rios, pela Água e pela Vida (Jornal Ilustrado, 2015).

Promotor de justiça substituto da Comarca de Goioerê salientou que está sendo feita uma nova abordagem para

05/15 evitar a construção das hidrelétricas na região, propondo a implantação de Áreas de Preservação Ambiental, que podem ser financeiramente mais vantajosas para os municípios (Goionews; CAOPMA, 2015).

11/15 Cicloturismo Alto Piquiri, que evidenciou as belezas associadas aos rios Piquiri e Goioerê (Pró Ivaí-Piquiri, 2015). Produtores rurais do assentamento Nossa Senhora Aparecida, em Mariluz-PR, decidiram sobre abaixo-assinados

01/16 destinados ao prefeito Municipal, requerendo que este firme dois termos de compromisso com a comunidade (Pró Ivaí-Piquiri, 2016).

01/16 Encontro de ciclistas em Alto Piquiri, que passou por Paiquerê e Apertado e evidenciou a importância da preservação da região (Pró Ivaí-Piquiri, 2016).

02/16 Reportagem "Voluntários revitalizam estrada para o Salto Paiquerê em Mariluz". Sobre limpeza de acesso às cachoeiras (Goionews; O Bemdito, 2016).

$1^{\circ}$ Encontro Viva os Rios, no Salto Paiquerê. Tratou da transformação de duas áreas significativas de mata nativa

03/16 em Reservas Particulares do Patrimônio Natural e da criação da Área de Proteção Ambiental municipal de Mariluz (Pró Ivaí-Piquiri, 2016).

FONTE: Adaptado de Gomes (2017). 


\section{Análise dos estudos de caso}

$\mathrm{O}$ enredo da PCH Dois Saltos demonstra um embate de interesses: a) intenções do município e de sua comunidade com as do estado e dos empreendedores; b) o privar a região de se desenvolver a partir do ecoturismo, no Salto que é símbolo local, e o produzir mais energia para o estado. E a questão não é o privar ou o permitir, mas considerar as possibilidades e tentar chegar em um acordo ou em um entendimento que permita a concessão, sem promover manifestações nem enfrentamentos entre as partes. Contudo, quem pretende se instalar e propõe privações é uma sociedade de empresas que já se desentenderam, se envolveram em processos judiciais e foram inseridas em investigações do MP-PR. Este último caso ocorreu devido às irregularidades no processo de licenciamento (identificadas pelo MP-PR) por sobrepujarem as etapas existentes, inclusive o meio ambiente e a sociedade - com o consentimento do IAP que, mesmo assim, permitiu o andamento do processo.

Os acontecimentos expostos demonstram a existência de basicamente três questionamentos feitos sobre a implementação da PCH Dois Saltos. Primeiro, sobre o impacto ao meio ambiente; segundo, sobre o impacto no turismo de Prudentópolis e região (relacionado diretamente ao meio ambiente); e terceiro, sobre as irregularidades no processo de licenciamento ambiental. Para compreender o questionamento de caráter ambiental, é importante lembrar que o empreendimento: prevê a construção de um túnel e canais interligando duas quedas (Salto Manduri e Salto Barão do Rio Branco); pretende se instalar no Rio dos Patos, cujo trecho médio inferior já possui duas PCHs. A tomada de água seria feita mil metros antes do Salto Manduri, por isso, há o receio de que toda esta pressão sobre o rio influencie negativamente o volume de água e, consequentemente, o desenvolvimento dos saltos. Tendo em vista o obstáculo anterior, o questionamento sobre o turismo concebe o comprometimento da "Terra das Cachoeiras Gigantes", que possui a intenção de virar um polo turístico, a partir de seus atrativos naturais.

A mais polêmica situação se dá sobre a dinâmica do licenciamento ambiental da PCH Dois Saltos. Foram identificadas irregularidades, como a falta de documentos e a consequente má decisão do órgão licenciador em prosseguir com o processo; a má divulgação de audiências públicas (Estado do Paraná, 2012); a ausência de autoridades no momento da participação pública; o modo errôneo como o estudo da PCH foi feito sobre a participação da população (há uma contradição sobre o aceite); a presença de problemas nos estudos e, por isso, o pedido de complementações do EIA/RIMA; o fato de o IAP não considerar a manifestação da população contrária, na concessão da licença; a "crise" do IAP, exposta por jornal da região, devido aos questionamentos sobre a concessão de licenças ambientais em todo o estado, por suspeita de relação de empreendimentos com o Secretário Estadual do Meio Ambiente e a Secretária de Ação Social - por isso, o Ministério Público tem visado o conflito de interesses no âmbito das licenças. Todavia, o IAP concedeu a licença prévia em 2012 e a ANEEL concedeu a outorga em 2015.

Já o enredo da PCH Água Limpa evidencia uma proposta de sobrepujar o meio ambiente, ao ser proposta a possibilidade de redução da área de preservação permanente, o que não é o problema em si, pois isso é previsto em alguns casos no novo Código Florestal e na Lei da Mata Atlântica. Mas, desconsidera-se a responsabilidade administrativa de um infrator ambiental e o seu dever cível de reparar esse dano. A compreensão é que o próprio empreendedor, que deve primar por preservar a APP 
que vai proteger seu reservatório, transcende essa infração e esse dever. E a situação do tombamento de um salto independe do empreendedor e do licenciamento, contudo, demonstra que nem sempre a demora no processo diz respeito ao mau desempenho do instrumento, mas que este tem se envolvido cada vez mais com movimentos sociais, os quais impõem cada vez mais seus propósitos que, se não são considerados como uma possibilidade por parte do empreendedor, promovem o enfrentamento de ambos e a morosidade do processo.

Neste caso, os acontecimentos demonstram que existem também três questionamentos feitos sobre a implementação da PCH Água Limpa, concernentes aos impactos ambientais, ao potencial turístico da região e às irregularidades no processo de licenciamento ambiental. O quesito ambiental é bastante abrangente, mas se evidencia principalmente pelo fato de o empreendimento ser projetado para ter sua barragem construída a apenas $50 \mathrm{~m}$ (acima) do Salto Paiquerê, no Rio Goioerê, importante afluente da margem direita do Rio Piquiri. Devido ao interesse sobre os atrativos do rio, o Município de Mariluz declarou seu trecho como de interesse cultural, natural e turístico. Atividades ambientais também são promovidas em prol da preservação do salto, como o Cicloturismo Alto Piquiri, a Trilha dos Rios, o Encontro Viva os Rios e a revitalização de estrada que leva ao salto.

Quanto às irregularidades no processo, o Ministério Público disseminou um informativo sobre um erro na publicidade da audiência pública, mais especificamente em seu edital de convocação, e um erro no EIA do empreendimento, pois estava exposto apenas o RIMA no site do IAP. Com isso, as audiências públicas foram prejudicadas pela falta de informação e algumas deixaram de ocorrer. Além disso, houve pouca divulgação sobre algumas audiências. Posteriormente, foi pedida complemen- tação dos estudos, com publicidade em novas audiências, visto que o EIA não preenchia os requisitos mínimos exigidos. Tendo em vista a insatisfação e a recusa da população, os empreendedores cogitaram apresentar propostas alternativas para a produção de energia, o que não ocorreu.

O Ministério Público, a partir de um ofício, recomendou a suspensão do licenciamento ambiental de empreendimentos hidrelétricos em todo o Paraná, devido a possíveis ilicitudes na concessão de licenças ambientais para a instalação de CGHs e PCHs. Suspeitava-se de um conflito de interesses envolvendo o Secretário Estadual do Meio Ambiente. Recomendou também o tombamento de trecho do Rio Goioerê, abrangendo o Salto Paiquerê, visto que o empreendimento possui inúmeras deficiências ambientais. A empresa organizou um relatório de respostas aos questionamentos das audiências públicas. Como consequência, houve forte atuação da população, de organizações, da universidade e de órgãos públicos em prol da não instalação da $\mathrm{PCH}$. Foram organizados estudos para o aproveitamento turístico dos atrativos da região e apresentadas propostas alternativas aos empreendimentos, como a criação de unidades de conservação, que serviriam como fonte de recursos para o município, por meio do ICMS Ecológico.

\section{Análise de conjunturas - Unidades de contexto}

As manifestações expostas foram agrupadas por analogia e codificadas (com auxíio do software ATLAS.ti), considerando os diferentes atores envolvidos e suas intenções sobre o processo inicial de licenciamento ambiental e, consequentemente, a implementação das PCHs. A partir disso, foram formadas seis unidades de contexto com os seguintes 
títulos: arbitrariedades, envolvimento do MP-PR, envolvimento político, envolvimento do setor privado, resistências sociais e desdobramentos. Esta última será comentada apenas no capítulo posterior.

\subsection{Unidade 1: Arbitrariedades}

Esta unidade está relacionada a três atores principais e fundamenta-se nas estratégias utilizadas por estes, no processo inicial de licenciamento ambiental, para alcançar seus objetivos. Isto é, as arbitrariedades dizem respeito às abordagens utilizadas sobre o instrumento (o não cumprimento das normas) e não aos objetivos dos atores em questão (que possuem lógicas bem definidas). Não se questiona a implementação dos empreendimentos, mas os artifícios utilizados para este fim.

a) Empreendedores: iniciam o licenciamento sem entregar determinados documentos ao órgão licenciador; entregam o estudo de impacto ambiental incompleto, não incorporam algumas informações, o que demandou o pedido de complementação do estudo apresentado; no estudo, consideram o aceite positivo da população local, mas nas audiências públicas todas as manifestações feitas pela população, e por outros atores, são contrárias à implementação da PCH; divulgou de maneira falha as audiências públicas; e, pela falta de informação, a população se vê refém dos empreendedores, por não compreender como ficará a questão do turismo local; ademais, soma-se o fato de que os empreendedores se propuseram a apresentar um projeto de geração de energia alternativo, devido à rejeição à $\mathrm{PCH}$, mas isso não ocorreu.

b) Órgãos licenciadores: o IAP dá continuidade ao licenciamento, mesmo antes de os empreendedores corrigirem as falhas citadas anteriormente; publicou em lugar irregular o ofício sobre a audiência pública; deixou de publicar o EIA em um momento essencial; desconsiderou as manifestações contrárias à $\mathrm{PCH}$; sobrepujou questões ambientais, como o fato de trecho de rio ter sido declarado, por lei, um patrimônio local; não utilizou esta informação e o tombamento provisório do salto para reorientar sua decisão e mudar o rumo do processo; desconsiderou o fato de uma possível área impactada ser reconhecida pelo MMA como Estratégica para a Conservação da Biodiversidade e, por parte do IPHAN, ser reconhecida como uma das maiores belezas do estado; é a razão de uma suspeita, levantada pelo MP-PR, de ilicitudes na emissão de licenças para projetos de empreendimentos hidrelétricos. AAssembleia Legislativa do Paraná também foi considerada um órgão licenciador, apesar de não acompanhar diretamente o desenrolar do instrumento. Possui discordâncias em seu interior (uma de suas comissões é contrária à LP); ou seja, sequer avalia a conduta dos diferentes atores envolvidos quanto ao cumprimento das legislações que constituem o licenciamento ambiental - não observa a diferença entre a promoção das determinações postas pelo licenciamento, com o acatamento das determinações -, antes de conceder a licença.

De acordo com Goldenberg \& Lucon (2007), pode-se dizer que a desestatização do setor dificultou o seu planejamento, pois a desregulamentação e a privatização ocorrentes se tornaram obstáculos à questão ambiental. Ou seja, o espaço adquirido pelo setor privado na gestão do setor, decorrente das mudanças do sistema energético, diminuiu e complexificou a área de atuação do governo que, por vezes, é influenciado pelas intenções de mercado visadas pelas empresas, e esse fato tem demandado um esforço ainda maior para a conquista de um resultado positivo no que diz respeito à implementação da democracia e à concretização do estabelecido para os instrumentos de gestão ambiental, dentre outros, inseridos no processo de licenciamento ambiental. 
Conforme Borinelli (2011), é possível assimilar o dilema presente na atuação do Estado que, ao mesmo tempo em que favorece a apropriação dos recursos naturais (pois cria essa condição para o mercado, que é quem regula os requisitos para a produção), tem de gerir os conflitos provocados pelo seu próprio ato, impondo restrições que envolvem a economia e a política das regiões visadas. E isto ocorre nos casos estudados, em nível estadual, pois o órgão ambiental favorece os empreendedores, enquanto tem que lidar com a problemática criada sobre a comunidade que será afetada também sobre o ambiente, a política e a economia local.

Zucarelli (2011) auxilia na compreensão de que a crítica feita ao licenciamento ambiental ocorre devido à atuação do órgão licenciador, que contribui com a flexibilização do instrumento - deteriorando direitos garantidos e normas ambientais específicas -, ao favorecer as empresas e sobrepujar questões fundamentais, impulsionando injustiças que comprometem diferentes aspectos das regiões em que se pretende implementar as PCHs.

As contribuições de Little (2003) permitem o entendimento de que a inserção das empresas na condição de preocupação ambiental promoveu alguns desafios técnicos e sociais, observados no decorrer da primeira fase do licenciamento das PCHs Água Limpa e Dois Saltos, tais como: a relação conflituosa de um grupo composto por diferentes atores sobre uma problemática ambiental; a limitada participação na gestão da política ambiental e de seus instrumentos, principalmente dos atores afetados e interessados; o tratamento setorial dado ao conflito ambiental, ou seja, a transversalidade da dimensão ambiental, que não é considerada corretamente pelo órgão licenciador nem pelos empreendedores; a inadequação da forma vigente de desenvolvimento econômico, que não incorpora de maneira efetiva as questões ambientais e sociais, principalmente no âmbito local; e o desentendimento ocorrente entre os diferentes níveis em que a política se faz, por exemplo, entre a intenção do Estado sobre a expansão energética em determinadas localidades e a resistência das comunidades que vivem nestas localidades.

Segundo Acselrad (2004), verifica-se que o comportamento destes atores condiz com o conflito ambiental proveniente do enfraquecimento das normas e agências públicas ambientais, ou seja, da desregulamentação ambiental - observada no não cumprimento do requisitado pelo licenciamento ambiental, especialmente quanto às audiências públicas e ao estudo de impacto, onde as necessidades ambientais e os interesses da comunidade afetada são sobrepujados. Essa situação deteriora a perspectiva democrática asseverada pelo governo e por suas políticas. Isto é, nos casos elencados, o conceito de conflito ambiental contempla a variável social e auxilia na composição da realidade desta no setor energético, mas, na prática, o social não é contemplado em processos onde os objetos em disputa são um recurso ambiental e o benefício financeiro

Winner (2001) auxilia no entendimento de que a tecnologia (como os projetos hidrelétricos) segue aliada ao lucro corporativo, visando ao poder econômico e à política, influenciando a sociedade - econômica e cotidianamente. Em outras palavras, e a partir dos estudos de caso, observa-se que as empresas do ramo se associam ao órgão licenciador e, com sua ajuda, sobrepujam políticas e seus instrumentos, a fim de implementar seus empreendimentos, que gerarão o poder econômico desejado. Neste cenário, a sociedade não é considerada, apenas prejudicada. Essa condição demonstra que a proposta de mudança tecnológica para determinada região - como a implementação de um projeto técnico de geração de energia - não é um problema, diferentemente da imposição social que é estabe- 
lecida a partir dessa proposta, cuja aproximação é baseada no ordenamento da sociedade.

Por fim, pode-se considerar, de acordo com Borinelli (2011), que a desregulamentação observada no setor, provocada pela atuação dos empreendedores e do órgão licenciador, reproduziu uma debilidade institucional em relação à política ambiental concernente ao campo energético, e esse fato contribuiu com o aumento dos obstáculos na relação entre os atores e potencializou as manifestações geradas.

\subsection{Unidade 2: Envolvimento do MP-PR}

As situações apresentadas evidenciaram que o MP-PR interveio fortemente nos dois casos elencados. Sua atuação foi um fator determinante no que diz respeito à anunciação das manifestações relacionadas ao processo inicial dos licenciamentos ambientais. Isto ocorreu, pois, apesar da normatização dos instrumentos ambientais, como o licenciamento e o estudo de impacto ambiental, nem todas as suas diretrizes são seguidas. A partir disso, pôde-se observar que o MP-PR se destacou de quatro maneiras:

a) Criando demandas: questionando irregularidades no licenciamento ambiental quanto ao estudo de impacto ambiental; a publicidade desse estudo e de audiências públicas; as leis criadas que deveriam inviabilizar o licenciamento.

b) Posicionando-se: contra o estabelecimento das PCHs (junto de outros atores), por meio da proposição de alternativas ao desenvolvimento das regiões, que visem à preservação do meio ambiente; com a participação em eventos com o mesmo propósito, com foco no potencial turístico da região; ressaltando a importância da mobilização social para a proteção do meio ambiente; e investigando desvios de conduta do órgão licenciador. c) Orientando gestores públicos: ao recomendar o tombamento do salto.

d) Recebendo demandas: da sociedade civil, quanto às irregularidades no licenciamento.

Esta unidade possibilitou compreender a extensão que a atuação do MP-PR tem tomado nos processos de licenciamento ambiental. Devido à debilidade consequente do Estado como instituição central na política ambiental (nestes casos representado pelo governo estadual), outras instituições (considerando as ideias e ideologias) passaram a influenciar sua dinâmica e seu desempenho (inclusive dos empreendedores), como as criadas pelo MP-PR - recomendações, contestações e ações.

Em suma, enquanto os direitos sociais são dissolvidos (como visto na criação e no recebimento de demandas), o MP-PR caracteriza-se como um instrumento em prol da cidadania (ao posicionar-se e ao sugerir determinado rumo para a política local). Nestes casos, a possibilidade de acionar o Poder Judiciário fundamenta a sua intervenção em diversos campos de atuação (como o ambiental), ao mesmo tempo em que justifica um outro nicho, o de influenciar o Poder Legislativo da região.

\subsection{Unidade 3: Envolvimento Politico}

Os estudos de caso evidenciam que, por um lado, há os que se colocam a favor das resistências sociais, contrárias à implementação do empreendimento, mas que não tomam atitudes concretas que firmem sua posição; por outro lado, observam-se o aumento e o avanço da atuação de representantes políticos que, de diferentes maneiras, buscam fortalecer sua opinião e a da população local, a partir da criação de leis; da promoção de eventos, sobre os quais participam e envolvem a sociedade; além de incorporarem diferentes grupos/ 
órgãos/especialistas, ou seja, com diferentes entendimentos, buscam alternativas para que a melhor das intenções seja a priorizada, considerando o pedido da população que se manifesta e a preservação da condição ambiental local. Claro que estes e outros casos são seguidos de mudanças de mandatos e de representantes. Esta situação pode ser admitida como hipótese, em termos políticos, para a compreensão do fato de que, em um momento, foi dada a anuência da cidade ao projeto do empreendimento e, em outro, surgiram tantos movimentos contrários ao mesmo projeto.

Esta unidade permite compreender a relação institucional presente entre os representantes políticos. Borinelli (2002) explica que, com a evolução do setor energético, o Estado adquiriu a função de regulador e, a partir de suas instituições, procura definir o processo político, pois, segundo North (1991), utilizando-se de normas, consegue delimitar o comportamento dos atores, influenciando suas percepções e, consequentemente, os momentos em que atuam na tomada de decisão. No entanto, como bem explica North (1993), há diferentes compreensões de mundo, pois cada pessoa possui diferentes valores ao seguir as normas. É por isso que os casos demonstram que nem todos os representantes políticos são influenciados a seguir as intenções do Estado que não correspondem às suas áreas de atuação.

\subsection{Unidade 4: Envolvimento do Setor Privado}

Um dos estudos de caso evidenciou a atuação do setor privado no processo de licenciamento ambiental. A FADCT, com um caráter mais social, principiou a questão do tombamento e a ideia das propostas alternativas visando ao potencial turísti- co e à preservação ambiental. Foi observado que, enquanto o poder público é influenciado pelas intenções do setor privado (até então externo à localidade visada), aquele que também faz parte do privado, mas que já está integrado à dinâmica local e possui um caráter mais social, sensibiliza-se mais às necessidades e interesses daquela comunidade. $\mathrm{Ou}$ seja, o "privado externo", que se aproxima baseado em uma lógica individualista e econômica, poderá ser coibido não só pela sociedade, mas por todos aqueles já estabelecidos, adaptados e acolhidos em determinada região.

Contudo, a importância desse tipo de atuação, advinda de empresas, pode ser melhor compreendida. Por exemplo, Dye (2014) explica que as instituições proporcionam determinadas características às políticas, como a legitimidade, a universalidade e a coerção. Portanto, quando Heidemann (2014) expõe que a política pode ser implementada por agentes públicos ou privados, pois aqueles que cumprem leis também se envolvem na produção da política, significa que a atuação dessa empresa, que visa aos interesses da sociedade e à preservação do meio ambiente, pode ser considerada como uma promoção do cumprimento daquilo que é estabelecido nas políticas, que a empresa atua promovendo a legitimidade desta. Deste modo, configura-se a dimensão da influência que a empresa pode ter sobre instituições formais que, hipoteticamente, não são sua competência, mas podem funcionar com sua participação.

\subsection{Unidade 5: Resistências Sociais}

Esta atuação está vinculada, principalmente, às diferentes formas de manifestação de grupos organizados, observadas de maneira direta - nas ruas, na Câmara de Vereadores, nas audiências 
públicas - e de maneira indireta - em redes sociais, sites de jornais, televisão, blog, rádio, por meio de abaixo-assinados. Grande parte das manifestações foi organizada por meio de redes sociais que, devido ao seu alcance, possibilitaram incorporar mais pessoas, grupos, órgãos e outros interessados em manifestar suas opiniões contrárias à implementação do empreendimento. As ações concentram-se sobre as irregularidades do processo inicial de licenciamento ambiental e sobre a preservação da natureza local, a partir da criação de eventos com práticas ao ar livre e de propostas como a criação de unidades de conservação e do tombamento de saltos. Partem de uma lógica coletiva, tanto que não tentam apenas impor sua ideia, mas integrá-la à dos outros atores. Isso ficou claro quando se propôs a apresentação de alternativas à geração de energia que contemplassem mais firmemente os recursos naturais locais - ao invés de ser pedido apenas o fim do processo de licenciamento.

Esta unidade demonstrou a abrangência (agrega pessoas, ações, etc.) das resistências sociais no processo de licenciamento ambiental. A partir de Little (2003), compreende-se que a debilidade institucional tem favorecido o destaque dos obstáculos e das manifestações desse conflito, e esse fato promove e evidencia o interesse e a atuação de outros atores/grupos sociais, como observado nos estudos de caso.

Não há uma preocupação com a contrapartida à sociedade que, por diversas vezes, expôs a preocupação com o turismo local, que até então era uma possibilidade considerada. E tanto os empreendedores quanto os órgãos licenciadores não respeitam os interesses da comunidade, que não sabe se o turismo será considerado caso a $\mathrm{PCH}$ seja implementada, bem como a possibilidade de sustento a partir do turismo.
Por isso, intensificam-se os enfrentamentos estimulados por estes atores de mesma intenção que, cada vez mais, se desvinculam de arenas formais e tradicionais de discussão pública e voltam-se a lugares informais e do cotidiano, como as ruas, a internet e, especificamente nestes casos, as trilhas e cachoeiras. A sociedade tem deixado de ser reproduzida por representantes, interpretada a partir daquilo que lhes é conveniente, e passa a intimidar e a pesar sobre as tomadas de decisão.

\section{Análise das dinâmicas de conflito}

A partir das situações expostas, e contando com o auxílio do software ATLAS.ti, compreende-se que o processo de licenciamento ambiental possui três dinâmicas - considerando apenas a sua fase inicial (do estudo até a concessão da licença prévia): a de arbitrariedades, a de enfrentamentos e a de desdobramentos.

Considerando a dinâmica de arbitrariedades como um conflito ambiental independente e os preceitos de Acselrad (2004), compreende-se que os atores refletem o conceito de natureza "ordinária", que é integrada aos interesses econômicos, visando à eficiência, à produtividade e à competitividade. $\mathrm{Ou}$ seja, tendem à concepção de que ela deve servir como um "custo de oportunidade" ao desenvolvimento socioeconômico. A dinâmica de enfrentamentos é caracterizada como um conjunto de manifestações provenientes do conflito gerado pela dinâmica anterior. Considerando os preceitos de Acselrad (2004), os atores da dinâmica de enfrentamentos tendem à concepção de natureza "ordinária" - que não visa exclusivamente ao capital e nem sempre é amparada pelo Estado, onde atuam os resistentes ao outro modelo, e o conflito provocado está baseado no enfraquecimento das normas e das agências pú- 
blicas ambientais (desregulamentação) - observado na dinâmica de enfrentamentos.

Analisando o embate entre as duas dinâmicas apresentadas anteriormente, e levando em conta o exposto por Zhouri \& Laschefski (2010), esta situação se caracteriza como um conflito ambiental de cunho territorial, pois engloba o interesse e as reivindicações de diferentes atores, que possuem diferentes modos de se apropriar de um recurso inserido em um mesmo recorte espacial. Ainda conforme os autores, caracteriza-se como um conflito ambiental também pelo fato de o planejamento referente à utilidade dessas localidades ser transferido à instância pública - órgão licenciador estadual -, que tem se aliado às empresas (cada vez mais independentes na busca de localizações e mercados, criam suas próprias territorialidades) e, consequentemente, a segmentos do capital, opondo-se às formas locais de organização do território.

Ademais, o embate evidenciado permite compreender a relevância de uma terceira dinâmica, a de desdobramentos. Ou seja, o enfrentamento provocado pelas arbitrariedades no processo inicial de licenciamento ambiental das PCHs originou determinadas situações. As evidenciadas pela pesquisa feita em diferentes meios de comunicação são: a publicação dos casos em artigos, monografias e dissertações; a repercussão promovida pela atuação da imprensa sobre os casos; o tombamento provisório emitido pela Secretaria de Estado da Cultura a um dos saltos; a atuação cada vez mais forte da sociedade em arenas informais, visto que a repercussão das formais (audiências públicas) geralmente é deturpada; a incorporação de diferentes instituições representativas (o MP-PR, a universidade, a empresa, etc.) nas discussões que envolvem o licenciamento ambiental; o prolongamento do licenciamento, na tentativa de barrá-lo; a criação de novos nichos de atuação - ou a reformulação dos já existentes (influências do MP-PR sobre o Poder Judiciário e dos movimentos sociais sobre a mídia).

Em suma, a trajetória criada a partir do encadeamento das três dinâmicas permite compreender que o comportamento dos atores envolvidos influencia os enfrentamentos e, principalmente, que as resistências sociais também influenciam as intenções dos empreendedores e órgãos licenciadores. Ou seja, se antes o Estado predominava, a partir de suas instituições, hoje é influenciado a partir das restrições e das imposições criadas pelos novos atores. O aumento do número de atores promove situações democráticas, por meio da criação de novos comportamentos (informais, levando em conta a limitação dos formais).

\section{Conclusão}

A análise dos estudos de caso demonstrou que a atuação de determinados atores não se orienta pelas normas que constituem o setor, visto que são observadas lacunas nos processos políticos e estas são evidenciadas por uma sequência de manifestações e enfrentamentos sociais, que tendem a perdurar e fortalecer o conflito ambiental a que correspondem, caso essa trajetória não seja compreendida e modificada.

A dinâmica de arbitrariedades, promovida pela desregulamentação ambiental, propicia o surgimento de diversas incertezas, que envolvem especialmente a comunidade afetada pelos empreendimentos propostos. Essa debilidade institucional (lacunas), observada no setor energético do Paraná, ocorre como consequência da não efetividade das políticas e legislações em um contexto institucional local.

Consequentemente, são criadas institucionalidades (estratégias), sobretudo informais, baseadas 
no poder de pressão, que se sobressaem às intenções individualistas (econômicas) - evidenciando a força de parcela da sociedade, que se renova e se assume como pertencente ao planejamento energético local, fortalecendo, consequentemente, a importância da dinâmica de enfrentamentos no cenário energético paranaense.

Este aprimoramento social promovido foi auxiliado pelos meios de comunicação de massa, sobretudo pelo emprego da internet como um instrumento de reforço da prática política, possibilitando que a comunidade (afetada e interessada) pressione e inspecione os outros atores para que considerem o interesse público e que este influencie na tomada de decisão de empreendimentos previstos para o setor. A internet apresenta-se como um instrumento de apoio à efetivação da perspectiva democrática prevista para o licenciamento ambiental, na realidade energética paranaense.

O problema em si não é o licenciamento ambiental como instrumento regulador, ou como um impasse ao desenvolvimento de empreendimentos, mas a sua implementação. Os dois estudos de caso demonstram que a execução do licenciamento ambiental, baseado na desregulamentação das normas, tem se constituído como um ponto nevrálgico do planejamento energético paranaense. $E$ isto se fundamenta no fato de que cresce o número de manifestações e enfrentamentos neste processo devido ao não cumprimento (eficaz) de suas etapas.

Com a soma de agentes (privados) sobre a prática de impor restrições à sociedade, o governo paranaense passou a basear-se em uma "desproporção da escolha pública", que ocorre entre o decidir sobre a viabilidade de projetos hidrelétricos e o mediar as discussões da sociedade com o setor privado e/ou o próprio Estado - acerca de rupturas de oportunidade (da escolha de como se desenvolver economicamente), privações (do meio ecologica- mente equilibrado) e consequências (impactos) que poderão ser promovidas pela implementação de determinado empreendimento. Essas duas questões são funções do governo, que deve gerir as situações distintas que se relacionam, mas provoca-se um desequilíbrio ao permitir que empreendedores sejam beneficiados, enquanto a sociedade interessada e a que poderá ser impactada não é bem informada nem considerada de maneira efetiva no EIA/RIMA, nas audiências públicas.

Contudo, avanços democráticos foram promovidos, com a criação de políticas/legislações relacionadas à produção de energia nas últimas décadas, as quais respaldam os cidadãos mobilizados e resistentes aos empreendimentos (da maneira como são postos), mas não foram suficientes para a democratização nos espaços de decisão, pois a gestão dos instrumentos e técnicas para este fim não foi aprimorada.

As situações que orientam as políticas vinculadas ao licenciamento ambiental são, basicamente, o protagonismo do setor privado no campo energético; a flexibilização das funções do Estado nesse sentido, onde estão inclusos os órgãos estaduais; e a perspectiva econômica que se sobressai à ambiental. Esse quadro tem sido negativo, por promover conflitos ambientais de cunho territorial e, por isso, contestado por diversos tipos de manifestações. Ademais, a importância do licenciamento ambiental, de sua contribuição sobre os empreendimentos hidrelétricos, se mantém, em razão da verificação de que o problema deste processo não é o instrumento, mas o tipo de gestão empenhada sobre este - em meio à influência dos interesses e poderes dos diferentes atores sociais que tendem a favorecer, nos casos estudados, a iniciativa privada em detrimento da noção de gestão da esfera pública.

Como consequência, os conflitos ambientais correspondentes ao processo inicial do licenciamento 
ambiental das PCHs constituem-se de três dinâmicas: a de arbitrariedades (promovida pelos órgãos licenciadores e pelos empreendedores); a de enfrentamentos (advindos do MP-PR, de representantes políticos, do setor privado e da sociedade); e a de desdobramentos (proveniente da relação entre as duas dinâmicas anteriores). São as condições formadas pela dinâmica de arbitrariedades que desestruturam os processos iniciais de licenciamento ambiental. A dinâmica de enfrentamentos, apesar de ser proveniente de manifestações, tem sido positiva, por promover a criação e/ou o ajuste (gestão) de institucionalidades; o cumprimento do instrumento; e a diminuição das manifestações relacionadas aos conflitos ambientais.

Finalmente, que os aspectos que envolvem os conflitos ambientais em torno dos estudos de caso estão diretamente relacionados ao comportamento/ atuação dos atores envolvidos no descumprimento das normas do setor energético, ou seja, da má gestão do processo. Deste modo, o estudo deixa evidente que, independentemente do aceite ou não da comunidade, o não cumprimento do estabelecido para o licenciamento não acelera o processo, muito menos beneficia o empreendedor ou o órgão licenciador. As incongruências apenas promovem, além da morosidade e da falta de legitimidade, a reestruturação do arranjo institucional do setor energético - novas convenções são criadas, na tentativa de que o instrumento ambiental contemple relações comunitárias e horizontais e reedifique a esfera pública, que não tem sido eficaz.

\section{Referências}

Acselrad, H. As práticas espaciais e o campo dos conflitos ambientais. In: Acselrad, H. (Org.). Conflitos ambientais no Brasil. Rio de Janeiro: Relume Dumará; Fundação Heinrich Böll, 2004.

Alonso, A.; Costa, V. Por uma sociologia dos conflitos ambientais no Brasil. In: Alimonda, H. (Ed). Ecologia Política. Naturaleza, sociedad y utopías. Buenos Aires: Clacso, 2002.

Andrade, A. de L.; Dos Santos, M. A. Hydroelectric plants environmental viability: strategic environmental assessment application in Brazil. Renewable and Sustainable Energy Reviews, 52, 1413-1423, 2015.

Bardin, L. Análise de conteúdo. 3 ed. Lisboa: Edições 70, 2011.

Bermann, C. Impasses e controvérsias da hidreletricidade. Estudos Avançados, 21(59), 139-153, 2007.

Borinelli, B. Instituições e política ambiental: notas teóricas e metodológicas. Anais do I Encontro da Associação Nacional de Pós-Graduação e Pesquisa em Ambiente e Sociedade - ANPPAS. São Paulo, 2002.
Borinelli, B. O "fracasso" da política ambiental: uma leitura teórica. Revista Espaço Acadêmico, 11(124), 130-137, 2011.

Brasil. Lei Federal n ${ }^{\circ} 6.938$, de 31 de agosto de 1981. Dispõe sobre a Política Nacional do Meio Ambiente. Diário Oficial da República Federativa do Brasil. Brasília, DF.

Bullard, R. Anatomy of Environmental Racism and the Environmental Justice Movement. In: Bullard, R. (Ed.). Confronting Environmental Racism. USA: South End Press, 1993.

Cia. Ambiental. Estudo de Impacto Ambiental e Relatório de Impacto Ambiental (EIA/RIMA) para a Pequena Central Hidrelétrica Água Limpa, 2012.

Coletti, R. N. A participação da sociedade civil em instrumentos da política ambiental brasileira. Desenvolvimento e Meio Ambiente, 25, 39-51, jan./jun. 2012.

Dagnino, R. Um Debate sobre a Tecnociência: neutralidade da ciência e determinismo tecnológico. 2007. Retrieved January, 8, 2009.

Dye, T. R. Mapeamento dos modelos de análise de políticas públicas. In: Heidemann, F. G.; Salm, J. F. (Orgs.). Politicas 
públicas e desenvolvimento: bases epistemológicas. 3. ed. Brasília: Editora Universidade de Brasília, 2014. 347 p.

Estado do Paraná. Poder Judiciário. Vara da Fazenda Pública de Prudentópolis. Ação popular no 0000126 83.2012.8.16.0139. Promovente: Gustavo de Brito Ribas. Promovidos: Dois Saltos Empreendimentos de Geração de Energia Elétrica Ltda. e Instituto Ambiental do Paraná. Prudentópolis, 2012.

Fleury, L. C.; Almeida, J. P. de. A construção da Usina Hidrelétrica de Belo Monte: conflito ambiental e o dilema do desenvolvimento. Ambiente \& Sociedade, São Paulo, SP, 16(4), 141-158, out./dez. 2013.

Fonseca, I. F. A construção de grandes barragens no Brasil, na China e na Índia: similitudes e peculiaridades dos processos de licenciamento ambiental em países emergentes. Texto para Discussão n. 1868. Rio de Janeiro: Instituto de Pesquisa Econômica Aplicada (IPEA), 2013.

Foschiera, A. A. Da barranca do rio para a periferia dos centros urbanos: a trajetória do movimento dos atingidos por barragens face ás políticas do setor elétrico no Brasil. Tese (Doutorado em Geografia na área de Produção do Espaço Urbano) - Universidade Estadual Paulista Júlio de Mesquita Filho, Presidente Prudente-SP, 2009.

Gazeta do Povo. Fundação quer impedir obra de $\mathrm{PCH}$, 2014. Disponível em: <http://www.gazetadopovo.com.br/ vida-e-cidadania/fundacao-quer-impedir-obra-de-pch-ecg7suiu6gvfla2bp96wzrtxq>. Acesso em: 15 maio 2016.

Goldemberg, J.; Lucon, O. Energia e meio ambiente no Brasil. Estudos Avançados, 21(59), 7-20, 2007.

Gomes, F. de F. Licenciamento ambiental e a difusão de conflitos: um estudo multicaso a partir de projetos hidrelétricos do Estado do Paraná. 2017. 130 f. Dissertação (Mestrado em Tecnologia e Sociedade) - UTFPR, Curitiba, 2017.

Guha, R.; Martinez-Alier, J. Varieties of Environmentalism. Earthscan, London, 1997.

Heidemann, F. G. Do sonho do progresso às políticas de desenvolvimento. In: Heidemann, F. G.; Salm, J. F. (Orgs.). Políticas públicas e desenvolvimento: bases epistemológicas. 3. ed. Brasília: Editora Universidade de Brasília, 2014. 347 p.

Lactec - Instituto de Tecnologia para o Desenvolvimento. Estudo de Impacto Ambiental e Relatório de Impacto Am- biental (EIA/RIMA) para a Pequena Central Hidrelétrica Dois Saltos, 2011.

Little, P. E. Políticas ambientais no Brasil: análises, instrumentos e experiências. São Paulo: Peirópolis, 2003.

North, D. C. Institutions. The Journal of Economic Perspectives, 5(1), 97-112, 1991.

North, D. C. The new institutional economics and development. Economic History, EconWPA, 1993.

Oliveira, C. M. de; Rebello, F. K.; Santos, M. A. S. dos; Santana, A. C. de. Usina hidrelétrica de Belo Monte: percepções dos atores locais quanto aos impactos socioeconômicos e ambientais. Espacios, 37(12), 5, 2016.

Ortiz Flórez, R. Pequenas Centrais Hidrelétricas. São Paulo: Oficina de Textos, 2014.

Piagentini, P. M.; Favareto, A. S. Instituições para regulação ambiental: o processo de licenciamento ambiental em quatro países produtores de hidreletricidade. Desenvolvimento $e$ Meio Ambiente, 30, 31-43, 2014.

Rampazo, A. V.; Ichikawa, E. Y. Identidades naufragadas: o impacto das organizações na (re)construção do universo simbólico dos ribeirinhos de Salto Santiago. Cad. EBAPE. BR, 11(1), 104-127, mar. 2013.

Schaeffer, C.; Smits, M. From matters of fact to places of concern? Energy, environmental movements and place-making in Chile and Thailand. Geoforum, 65, 146-157, 2015.

Siciliano, G.; Urban, F.; Kim, F.; Lonn, P. D. Hydropower, social priorities and the rural-urban development divide: The case of large dams in Cambodia. Energy Policy, 86, 273-285, 2015.

Silva, C. L. da; Nowakowski, G. A. A.; Santoyo, A. H.; Leon, V. E. P.; Vilardell, M. C. Análise de possibilidade de expansão das Pequenas Centrais Hidroelétricas no Brasil: um estudo dos limitantes e potencialidades da cadeia produtiva à luz da sustentabilidade. Meio Ambiente e Desenvolvimento. Edição Especial Nexo Água e Energia, 37, 47-72, maio 2016.

Tsoutsos, T.; Maria, E.; Mathioudakis, V. Sustainable siting procedure of small hydroelectric plants: The Greek experience. Energy Policy, 35(5), 2946-2959, 2007.

Vaccarezza, L. S. Ciencia, Tecnología y Sociedad: el estado de la cuestión en América Latina. Ciência \& Tecnologia Social, 1(1), 2011. 
Winner, L. Artefatos têm política? Artigo traduzido por Fernando Pereira Manso para disciplinas de Mestrado e Doutorado do Núcleo de Computação Eletrônica-UFRJ. Rio de Janeiro, 2001.

Zhouri, A. (Org.). As tensões do lugar: hidrelétricas, sujeitos e licenciamento ambiental. Belo Horizonte: Editora UFMG, 2011.

Zhouri, A.; Gomes, L. A. Da invisibilidade à resistência atores-rede no licenciamento ambiental das hidrelétricas Capim Branco I e II (Complexo Amador Aguiar), MG.
In: Zhouri, A. (org.). As tensões do lugar: hidrelétricas, sujeitos e licenciamento ambiental. Belo Horizonte: Editora UFMG, 2011.

Zhouri, A.; Laschefski, K. Conflitos ambientais. In: Zhouri, A.; Laschefski, K. Desenvolvimento e conflitos ambientais. Belo Horizonte: UFMG, 2010.

Zucarelli, M. C. O papel do termo de ajustamento de conduta no licenciamento ambiental de hidrelétricas. In: Zhouri, A. (Org.). As tensões do lugar: hidrelétricas, sujeitos e licenciamento ambiental. Belo Horizonte: Editora UFMG, 2011. 